Вісник Дніпропетровського університету. Серія: геологія, географія. 25 (1), 2017, 12 - 18.

Vìsnik Dnìpropetrovs'kogo unìversitetu. Serìâ Geologîa, geographìâ

Dnipropetrovsk University Bulletin. Series: geology, geography. 25 (1), 2017, 12 - 18.

Doi: $10.15421 / 111702$

http://geology-dnu.dp.ua

УДК 556.491.622

\title{
Математичні моделі зміни гідрогеологічних умов територій, прилеглих до ставків- накопичувачів скидних шахтних вод
}

\author{
Г. П. Свграшкіна, А. С. Горб, Л. В. Доценко \\ Дніпровський національний університет імені Олеся Гончара, Дніпро, Украйна, е-таil: hydrogeo44@gmail.com
}

Видобуток вугілля у Західному Донбасі супроводжусться інтенсивним водовідводом. Шахтні води мають підвищену мінералізацію та акумулюються у ставках-накопичувачах, які побудовані без екранізації водовмісної частини. Негативним наслідком їх експлуатації стає забруднення водовмісних горизонтів по вертикалі й у плані. Одна 3 актуальних проблем цього регіону -- наукове обгрунтування комплексу природоохоронних заходів гідрогеологічного спрямування для боротьби 3 підтопленням прилеглих до ставків територій, підвищенням мінералізації підземних вод і вторинним засоленням грунтів і порід зони аерації внаслідок двох перших факторів. Науковою основою вирішення цих проблем бачиться розв'язання багатоваріантних прогнозних задач для зони повного водонасичення за процесами фільтрації і масопереносу на запропонованій математичній моделі. Принципи ії побудови викладені у даній публікації на прикладі ставка-накопичувача Балка Таранова. Математична модель зміни гідрогеологічних умов території, прилеглої до ставка, складається із двох частин - фільтраційної і міграційної, побудованих на основі гідродинамічної сітки. Для однозначного вибору гідродинамічної схеми фільтраційної частини та виду диференційного рівняння, яким описується процес зміни рівня підземних вод на досліджуваній території, першим етапом моделювання розв'язусться індуктивна гідрогеологічна задача із застосуванням рівнянь Лапласа, Пуассона та двох модифікацій Фур'є. Друга частина - масопереносу також починається з вибору оптимальної міграційної схеми шляхом співставлення результатів розрахунків із режимними спостереженнями. За режимними спостереженнями виконуються також інверсні й епігнозні задачі. Заключний етап - прямі прогнозні багатоваріантні задачі, їх аналіз і природоохоронні рекомендації.

Ключові слова: міграчія; фільтрачія; математична модель; метод подвійної суперпозицї̈; неупорядкована

макродисперсія

\section{Mathematical models of changes in hydro-geological conditions of territories adjacent to tailing ponds of discharged mine water}

\author{
G.P. Evhrashkina, A.S. Horb, L.V. Dotsenko
}

Oles Honchar Dnipropetrovsk National University, Dnipro, Ukraine, hydrogeo44@ gmail.com

Coal mining in the Western Donbas is conducted along with intense water drainage. Mine water has heightened mineralization and accumulates in tailing ponds, which were built without barriers screening the water-containing rocks. The negative consequence of their usage is contamination of water-bearing horizons along the vertical and in the top view. One of the relevant problems of the region is to elaborate a scientifically grounded plan for taking a complex of hydro-geological nature protection measures for preventing the flooding of the areas adjacent to the ponds, heightening of the ground water mineralization and secondary salinization of the soils and the rocks of the aeration zone as a result of first two factors. A scientific basis for overcoming these problems is solving multi-variant prognosis tasks for the zone of full water saturation as a result of the filtration process and mass transfer on the proposed mathematical model. Its structural principles are stated in this article on the example of a tailing pond Balka Taranova. The mathematical model of changes in the hydro-geological conditions of the territory adjacent to the pond consists of two parts - filtration and migration parts, arranged using a flow network. For a clear choice of a flow network of the filtration part and the type of differential equation which describes the process of change in the ground water level in the studied territory, the first stage of the modelling solves the inductive hydrogeological task using Laplace`s equation, Poisson`s equation and two modifications of Fourier transforms. The second part, heat transfer, also starts with selection of the optimum migration scheme by comparing the results of calculations with the regime observations. Along with the regime observations, inversion and epignosis tasks are solved. The final stage is direct prognosis of multi-variant tasks, their analysis and recommendations for nature protection.

Keywords: migration; filtration; mathematical model; double superposition principle; unregulated macro-dispersion. 
Вступ. Західний Донбас - потужний гірничодобувний регіон України. Наразі тут працюють 10 вугільних шахт. Видобуток вугілля супроводжується інтенсивним водовідливом підземних вод підвищеної мінералізації, які акумулюються у ставках-накопичувачах, побудованих у глибоких ерозійних врізах на територіях шахтних полів у балках Косьминна, Таранова, Глиняна, Ніколіна, Свідовок без екранізації водовмісної частини. Методика побудови математичної моделі розглянута на прикладі ставка Балка Таранова. Відсутність водонепроникного екрана тут і в інших ставках безпідставно аргументується таким чином: частина води може надходити у водоносні горизонти, тому що вони наділені властивістю самоочищення. Але у (Евграшкина, 2003; Евграшкина,) доказано таке: під час наукового обгрунтування, планування, розроблення та втілення природоохоронних заходів гідрогеологічного спрямування не слід розраховувати на самоочисну здатність водоносних горизонтів шляхом сорбції макрокомпонентів водовмісними породами.

Математичні моделі зміни гідрогеологічних умов техногенно порушених територій - обов'язкова частина сучасного гідрогеологічного моніторингу. Вони використовуються для розв'язання багатоваріантних прогнозних задач, результати яких кількісно характеризують підтоплення територій і процеси забруднення підземних вод у просторі i часі для наукового обгрунтування комплексу природоохоронних заходів у частині водних ресурсів.

Геолого-гідрогеологічна характеристика об' єкта досліджень. Ставок-накопичувач Балка Таранова розташований на полі шахти «Самарська». Він уведений в експлуатацію в 1972 р. Гребля відсипана із суглинків. Відмітки горизонтів води: максимальний підпірний 81,1 м; нормальний підпірний $-80,1$ м; мінімальний - 77,3 м. Глибина: максимальна 5,5 м, середня - 2,9 м. Площа дзеркала: при максимальному горизонті - 0,42 км²; при нормальному - 0,3 км². Втрати води на випаровування 3 водної поверхні - 230 тис. $\mathrm{m}^{3} /$ рік; на фільтрацію - 300 тис. $\mathbf{m}^{3} /$ рік. Надходження води охарактеризовано в таблиці 1. Мінералізація води в різні періоди експлуатації змінювалась від 17 до 3,8 г/дм ${ }^{3}$. Наразі вона становить 5,9 г/дм ${ }^{3}$.

Табличя 1

Характеристика шахтного скиду

\begin{tabular}{|c|c|c|c|c|c|c|c|c|c|}
\hline \multirow{2}{*}{$\begin{array}{c}\text { Назва ставка, } \\
\text { об'єм, } \\
\text { тис. м } \\
\text { сумарний скид, } \\
\text { млн, м³ } / \text { рік }\end{array}$} & \multirow[b]{2}{*}{$\begin{array}{c}\text { Шахти, які } \\
\text { скидають воду }\end{array}$} & \multicolumn{2}{|c|}{$\begin{array}{l}\text { Кількість води, } \\
\text { яка скидається }\end{array}$} & \multicolumn{2}{|c|}{ Мінералізація, г/дм } & \multicolumn{2}{|c|}{$\begin{array}{c}\text { Середньозважена } \\
\text { мінералізація, г/дм }\end{array}$} & \multirow[b]{2}{*}{ Тип води } & \multirow{2}{*}{$\begin{array}{c}\text { Мінералі- } \\
\text { зація води у } \\
\text { ставку, } \\
\text { г/дм³, } \\
\text { жовтень } \\
2015 \text { р. } \\
\end{array}$} \\
\hline & & $1990 \mathrm{p}$. & 2013 p. & $1990 \mathrm{p}$. & 2013 p. & 1990 p. & 2013 p. & & \\
\hline $\begin{array}{l}\text { Балка Таранова } \\
2100 ; 17,8\end{array}$ & $\begin{array}{c}\text { «Самарська» } \\
\text { «Діпровсь-ка» } \\
\text { ім. Сташкова }\end{array}$ & $\begin{array}{c}6,50 \\
5,38 \\
20,78\end{array}$ & $\begin{array}{c}10,87 \\
6,71 \\
22,31\end{array}$ & $\begin{array}{l}7,1 \\
6,6 \\
3,2\end{array}$ & $\begin{array}{c}5,8 \\
12,1 \\
2,5\end{array}$ & 4,54 & 5,014 & $\begin{array}{c}\text { Хло- } \\
\text { ридні } \\
\text { натрієві }\end{array}$ & 5,9 \\
\hline
\end{tabular}

Геологічний розріз території, прилеглої до ставка (рис.1), за напрямком до р. Самара у верхній частині представлений четвертинними суглинками середньою потужністю $m_{o}=10,0$ м із коефіцієнтом фільтрації $K_{\phi}-0,1$ м/добу. На відстані 2500 м від греблі вони виклинюються. Нижче за розрізом розташовані берекські та межигірські піски дрібнозернисті, нерівномірно глинясті, загальною потужністю $16,2-24,9$ м із коефіцієнтом фільтрації $3,1-5,9$ м/добу. Активна пористість цих відкладів дорівнює 0,175 частки одиниці. Ці відклади підстеляються обухівськими пісковиками 3 коефіцієнтом фільтрації 0,001 м/добу. $\mathrm{y}$ прогнозних розрахунках вони розглядаються як відносний водотрив.

Мета досліджень. Результати досліджень, наведені у цій статті, $є$ подальшим розвитком і вдосконаленням раніше виконаних $\mathrm{i}$ опублікованих. Зокрема застосовано нові методи розв'язання фільтраційних і міграційних задач, враховано зміни гідрогеологічних умов сучасного періоду експлуатації ставка. Додаткові режимні спостереження дозволили уточнити граничні умови. Прогнозні задачі розв'язані на більш тривалі строки.

Для гірничої частини Західного Донбасу створено постійно діючу математичну модель (ПДММ) зміни гідрогеологічних умов. В основу 
iii покладено комплексну програму «Прогноз I», розроблену в лабораторії гідрогеологічних прогнозів i охорони підземних вод Дніпропетровського відділку Українського державного геологорозвідувального інституту. Серед множини безсумнівних переваг ПДММ має один недолік - масштаб 1 : 100 000. Модель такого масштабу дає лише загальну характеристику техногенних змін режиму підземних вод досліджуваного регіону і не може бути єдиною науковою основою для розроблення природоохоронних заходів гідрогеологічного спрямування. Інформація, одержана на ПДММ, недостатня i повинна доповнюватись великомасштабними прогнозами на територіях, прилеглих до локальних джерел забруднення підземних вод. У Західному Донбасі - це ставкинакопичувачі скидних шахтних вод i шахтні відвали, відсипані на схилах, у природних i штучних зниженнях рельєфу (просадових ділянках). Предмет досліджень - ставкинакопичувачі.
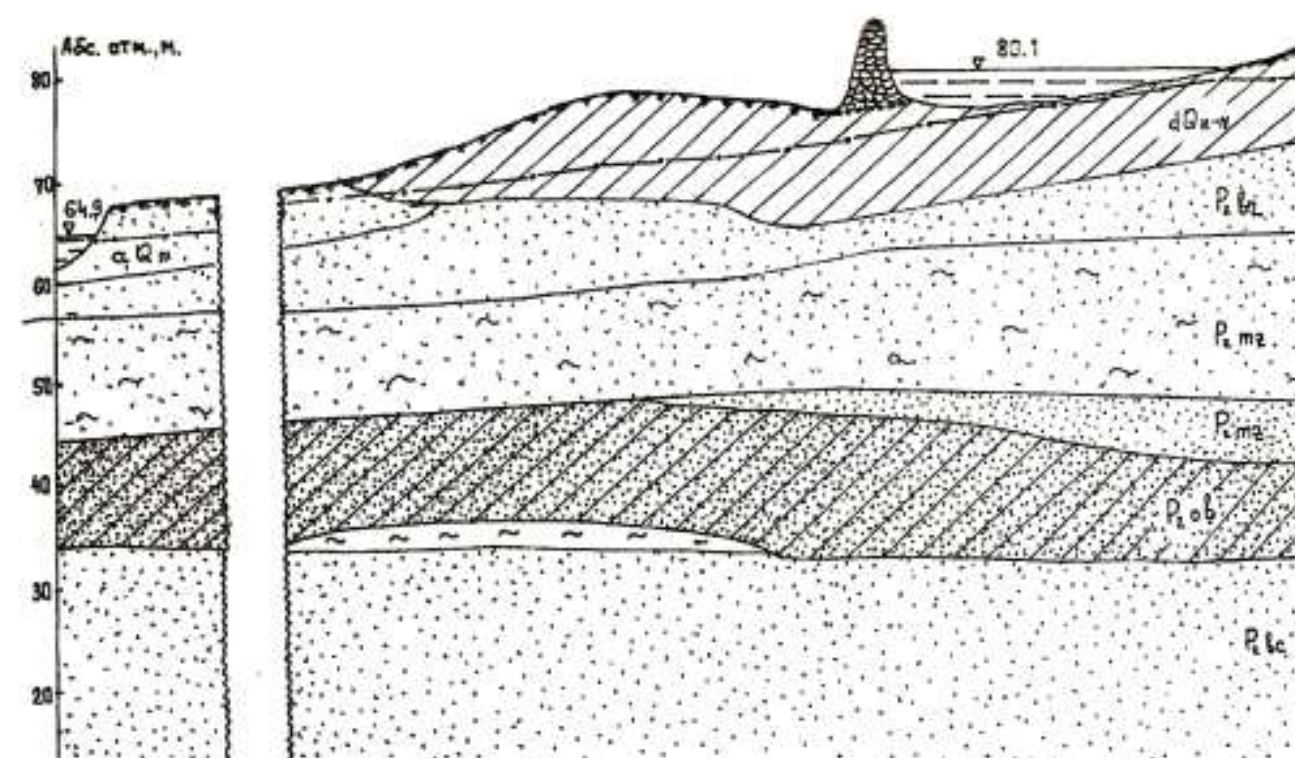

Рис. 1. Геологічний розріз території

Характеристика складових частин моделі. Математична модель зміни гідрогеологічних умов території, прилеглої до ставканакопичувача - джерела забруднення підземних вод, складається з двох частин - фільтраційної та міграційної. Фільтрація у загальному вигляді описується тривимірними рівняннями математичної фізики еліптичного та параболічного типів другого порядку в частинних похідних. Складова гідродинамічного напору за координатою $Z$ значно менша складових за $X$ і $Y$, тому нею можна знехтувати. Двовимірні рівняння фільтрації не мають аналітичних розв'язків для ділянок неправильної форми та складної конфігурації. Класики математичного моделювання гідрогеологічних процесів, В.М. Шестаков і В. О. Мироненко (1979; 1993) пропонують застосувати два методичні підходи до розв'язання задач планової фільтрації у такій постановці. Перший підхід: будується гідродинамічна сітка та за токовими лініями току аналітичними методами розв'язується система одновимірних рівнянь виду:

$$
\frac{d^{2} H}{d x^{2}}+\frac{W}{T}=\frac{1}{\mathrm{a}^{*}} \frac{d H}{d t}
$$

де $H$ - гідродинамічний напір, м;

$W$ - інфільтраційне живлення, м/добу;

$T$ - водопровідність, м²/добу;

$d$ - загальна похідна;

$a^{*}-$ п'єзопровідність, м²/добу;

$x$ - просторова координата, м;

$t$ - часова координата, діб.

Другий підхід: двовимірне рівняння фільтрації розв'язується у скінченнорізницевій формі. Перший підхід спеціалісти-гідрогеологи вважають більш доцільним, тому що він застосовує аналітичні рішення на основі 
гідродинамічної сітки, яка відображує структуру фільтраційного потоку, а токові лінії току моделюють траєкторії руху часток води. У другому варіанті двовимірні рівняння розв'язуються наближеними методами. Задача у такій постановці аналітичного розв'язку не має, тому застосовуємо перший варіант - модель на основі гідродинамічної сітки. Для однозначного вибору гідродинамічної схеми та виду диференціального рівняння, яким описується процес зміни рівня підземних вод на досліджуваній території, розрахунки виконуються за рівняннями Лапласа, Пуассона, Фур'є у двох модифікаціях і порівнюються 3 режимними спостереженнями. Прогнозні довгострокові різнопланові задачі розв'язуються після вибору адекватних рівнянь і розв'язання інверсних задач також на основі режимних спостережень. Найкращі результати досягнуті із застосуванням методу подвійної суперпозиції.

Міграційна частина. Перенесення розчиненої речовини 3 фільтраційним потоком має назву «міграція підземних вод» (1979) або «масоперенос у підземних водах» (Мироненко, 1993). Сучасні методи прогнозу переносу речовини підземними водами біля джерел забруднення розроблені на основі теорії фізикохімічної гідродинаміки пористих середовищ, згідно з якою ці процеси описуються рівняннями руху та збереження маси речовини (2003).

Кількість і характер початкової інформації, одержаної на режимній спостережній мережі свердловин, дозволяють у побудові моделі та наступних розрахунках на ній використовувати часткові аналітичні, числово-, числовоаналітичні розв' язання такого рівняння:

$$
D \frac{d^{2} C}{d x^{2}}-V \frac{d C}{d x}=m \frac{d c}{d t},
$$

де $D$ - коефіцієнт гідродисперсії, комплексний узагальнений параметр, який враховує всі фактори розсіювання речовини, супутні 3

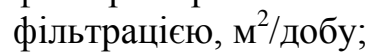

$C$ - мінералізація підземних вод, г/дм³

$V$ - швидкість фільтрації, м/добу;

$m$ - активна пористість, частки одиниці;

$x$ - просторова координата, м;

$t$ - часова координата, діб.

У наукових дослідженнях проблеми масопереносу підземними водами для створення моделі задіяні чотири розрахункові схеми: поршневе витіснення, упорядкована мікродисперсія та неупорядкована макро- i мікродисперсія (Евграшкина). Для однозначного вибору розрахункової схеми, яка відповідає досліджуваним гідрогеологічним умовам, виконано серію епігнозних розрахунків за кожною 3 названих схем i порівняння їx результатів із натурними спостереженнями. Зроблено висновок, що гідрогеологічним умовам досліджуваної території найточніше відповідає міграційна схема «неупорядкована макродисперсія». Створена математична модель розв'язує прямі, обернені, інверсні, узагальнені, індуктивні задачі фільтрації та масопереносу.

Перший етап усіх досліджень на моделі це розв'язання інверсної задачі для визначення міграційних параметрів - коефіцієнтів рівняння (2) $D, v, m$. Активна пористість $m$ визначена лабораторним шляхом у Павлоградській геологорозвідувальній експедиції. Швидкість фільтрації $v$ визначається за законом Дарсі. Другий варіант - це використання граничних умов:

$$
\mathrm{V}=\frac{\mathrm{H}_{\mathrm{cr}}-\mathrm{H}_{\mathrm{p}}}{\mathrm{L}} \times \kappa, \mathrm{M} / \text { добу, }
$$

де $H_{\text {ст }}$ - абсолютна відмітка поверхні води у ставку, м;

$H_{\mathrm{p}}$ - абсолютна відмітка води в річці, м;

$L-$ відстань між урізами води, м.

Для міграційної схеми «неупорядкована макродисперсія» використана формула В. М. Шестакова (Шестаков, 1979) з визначення параметра $D$ :

$$
\mathrm{D}=\delta_{2} \times \mathrm{v}^{2},
$$

$$
\delta_{2}=\frac{m \times m_{0}}{2 D_{m}\left(1+\frac{m \times n}{m_{0} \times n_{0}}\right)}
$$

де $m$ - потужність добрепроникного шару, м; $m_{0}$ - потужність слабкопроникного шару, м; $n$ - активна пористість добрепроникного шару, частки одиниці;

$D_{m}$ - коефіцієнт молекулярної дифузії, м²/добу.

Другий етап - розв'язання прямих задач масопереносу, які поділяються на два види: епігнозні та прогнозні. Епігнозні виконуються на період часу, вже охарактеризований пошуковими величинами, у даному випадку мінералізацією підземних вод. Якщо розраховані результати та визначені за даними режимних спостережень збігаються, то це $є$ ознакою правильності вибору розрахункової схеми та визначення міграційних 
параметрів. Гідрогеологічний прогноз - це характеристика гідрогеологічного процесу у майбутньому часі. Прогнозні задачі на різні строки розв'язуються для наукового обгрунтування комплексу природоохоронних заходів гідрогеологічного напряму. Розв'язання рівняння (2) здійснюється аналітичними та числовими методами. Аналітичним методам завжди надається перевага. Для класичних задач масопереносу за схемою «неупорядкована макродисперсія», яка за доказом відповідає гідрогеологічним умовам досліджуваної територіі, застосовуються два аналітичні розв'язання рівняння (2) за кожною токовою лінією:

1) напівобмежений шар iз граничною умовою I роду по урізу води у ставку. У науковій літературі воно має назву «фундаментальне розв’ язання Карслоу-Сгера» (Самарский, 1977).

2) напівобмежений шар is граничною умовою III роду по урізу води у забруднювальному ставку або хвостосховищі (Brenner, 1978). Другий варіант у попередніх дослідженнях не розглядався через відсутність на момент опублікування інформації про глинястий прошарок по дну ставка.

Вони мають вигляд:

1.

2 .

$$
\bar{c}=0,5 \times\left[\operatorname{erfc} \varepsilon+e^{\frac{v x}{D}} \times \operatorname{erfc} \varepsilon^{\prime}\right]
$$

$$
\varepsilon=\frac{x-\frac{v t}{m}}{2 \sqrt{\frac{D_{1} t}{m}}}, \quad \frac{x+\frac{v t}{m}}{2 \sqrt{\frac{D t}{m}}} .
$$

3.

$$
\begin{gathered}
\bar{c}=0,5 \times\left[\operatorname{erfc} z_{2}+e^{z_{1}^{2-} z_{2}^{2}} \times\left(\operatorname{erfc} z_{1}-4 \operatorname{aierfcz_{1}}\right)\right. \\
C=\bar{C} \times\left(C^{o}-C_{o}\right)+C_{o} .
\end{gathered}
$$

У виразах (5)-(6) застосовані такі позначення: $\bar{C}-$ приведена мінералізація підземних вод, безрозмірна величина;

$C^{o}$ - мінералізація води у ставку, г/дм³

$C_{o}$ - мінералізація води у водоносному горизонті на момент часу $t=0, \Gamma /$ д $^{3}$.

Тільки для задач у такій постановці коефіцієнт гідродисперсії доцільно розраховувати за формулою [1]:

$$
D=\frac{v L}{2 \ln \frac{C^{o}}{C_{p}}},
$$

де $L-$ відстань між урізами води у ставку та річці, м; $C_{p}$ - мінералізація води у річці, г/дм³ Інші позначення наведені раніше.

На досліджуваній території виконувались режимні спостереження за зміною мінералізації підземних вод у просторі та часі (Евграшкина, ). Одержану інформацію використано для визначення коефіцієнта гідродисперсії числовим методом таким чином. Рівняння (2) записується у скінченнорізницевій формі за явною і неявною схемами для рівномірного та нерівномірного розташування спостереження свердловин (рис. 3)

$$
\begin{gathered}
D\left[\frac{C_{i-1}^{\tau}-2 C_{i}^{\tau}+C_{i+1}^{\tau}}{(\Delta x)^{2}}\right]-v \times \frac{C_{i-1}-C_{i}}{\Delta x}=m \times \frac{C_{i}^{\tau+1}-C_{i}^{\tau}}{\Delta t} ; \\
D\left[\frac{C_{i-1}^{\tau+1}-2 C_{i}^{\tau+1}+C_{i+1}^{\tau+1}}{(\Delta x)^{2}}\right]-v \times \frac{C_{i-1}^{\tau+1}-C_{i}^{\tau+1}}{\Delta x}=m \times \frac{C_{i}^{\tau+1}-C_{i}^{\tau}}{\Delta t} ; \\
D\left[\frac{C_{i-1}^{\tau}-C_{i}^{\tau}}{\Delta x_{1}}-\frac{C_{i}^{\tau}-C_{i+1}^{\tau}}{\Delta x_{2}}\right] / \frac{\Delta x_{1}+\Delta x_{2}}{2}-v \times \frac{C_{i-1}^{\tau}-C_{i}^{\tau}}{\Delta x_{1}+\Delta x_{2}}=m \times \frac{C_{i}^{\tau+1}+C_{i}^{\tau}}{\Delta t} ; \\
D\left[\frac{C_{i-1}^{\tau+1}-C_{i}^{\tau+1}}{\Delta x_{1}}-\frac{C_{i}^{\tau+1}-C_{i+1}^{\tau}}{\Delta x_{2}}\right] / \frac{\Delta x_{1}+\Delta x_{2}}{2}-v \times \frac{C_{i-1}^{\tau+1}-C_{i}^{\tau+1}}{\Delta x_{1}+\Delta x_{2}}=m \times \frac{C_{i}^{\tau+1}+C_{i}^{\tau}}{\Delta t} .
\end{gathered}
$$


У виразах (8)-(11) застосовані такі позначення:

$i-1, i, i+1-$ просторові індекси розрахункових точок (свердловин);

$\tau, \tau+1-$ часові індекси, попередній і наступний через крок $\Delta t$;

$\Delta x, \Delta x_{1}, \Delta x_{2}-$ відстані між розрахунковими точками, м.

Інші позначення наведено раніше.

Мінімальний обсяг інформації для застосування скінченорізницевих рівнянь (8)(11) - режимні спостереження на два моменти часу за трьома свердловинами:

$$
\begin{aligned}
& \begin{array}{cccc}
C_{i-1} & & C_{1} & \\
\hline & C_{i+1}
\end{array} ; \\
& \frac{C_{i-1} \quad C_{1} \quad C_{i+1}}{\Delta x_{1}} \quad \Delta x_{2} \text {; }
\end{aligned}
$$

\section{Розв'язання гідрогеологічних задач.}

Фільтрація та масоперенос взаємопов'язані. Фільтраційна прогнозна задача $є$ науковою основою для обгрунтування та розроблення комплексу заходів із боротьби 3 підтопленнями прилеглих до ставка територій. За результатами прогнозу рівневого режиму визначається швидкість фільтрації у порушених умовах. Вона $\epsilon$ головним фактором забруднення підземних вод i важливим параметром у рівнянні масопереносу. Фільтраційні задачі. Перший етап досліджень це завжди побудова гідродинамічної сітки, яка відображає структуру фільтраційного потоку. На рисунку 2 зображено сітку на кінець 1995 року. Цей період характеризується максимальною кількістю режимних спостережень. Карту гідроізогіпс водоносного комплексу олігоценміоценових і четвертинних відкладів побудувала Павлоградська геологорозвідувальна експедиція. Другий етап - розв'язання індуктивної
задачі диференціального рівняння, яким описується досліджуваний процес. Методика розв'язання задачі полягає у багатоваріантних розрахунках, результати яких порівнюються iз режимними спостереженнями за такими варіантами.

Варіант 1. Розрахункова гідродинамічна схема «шар - смуга» із границями першого роду - ставок i річка. Розрахунки виконані за рівнянням Лапласа. Результати розрахунку не узгоджуються із режимними спостереженнями.

Варіант 2. Застосована та сама гідродинамічна схема, але розрахунки виконуються за неаналітичним розв'язанням рівняння Пуассона. Узгодження результатів із режимними спостереженнями незадовільне.

Варіант 3. Розрахунки виконуються за аналітичним розв'язанням рівняння Фур'є методом подвійної суперпозиції. Результати розрахунків останнього варіанта практично повністю збіглися 3 режимними спостереженнями. Його рекомендовано застосовувати у подальших дослідженнях для розв'язання прямих прогнозних задач на різні строки.

На завершальному етапі розв'язуються прямі прогнозні фільтраційні задачі, результати яких використовуються для обгрунтування комплексу природоохоронних заходів.

Міграційні задачі. Для характеристики забруднення підземних вод за впливу фільтраційних втрат зі ставка-накопичувача застосовано схему «неупорядкована макродисперсія». Попередніми дослідженнями (Yevgrashkina G.P., 2003) вона вибрана найбільш відповідною досліджуваним гідрогеологічним умовам території, прилеглої до ставка. Для доведення адекватності моделі виконано епігнозний розрахунок строком на 23 роки від початку експлуатації, охарактеризований картою мінералізації. Розрахункова карта збігається із фактичною практично за усіма токовими лініями. Пряма прогнозна задача розв'язана до 2028 року. За результатами прогнозу процес забруднення на цей період часу стабілізується.

Висновки. 1. Математичні моделі зміни гідрогеологічних умов територій, прилеглих до локальних джерел забруднення, - важлива й обов'язкова складова сучасного гідрогеологічного моніторингу.

2. Найбільш ефективна за точністю відображення гідрогеологічних процесів і достовірності результатів модель на основі гідродинамічної сітки.

3. Аналіз результатів режимних спостережень і числових експериментів показує, що для опису процесів міграції речовини, яка забруднює підземні води, найбільш доцільна схема «неупорядкована макродисперсія».

4. Процес забруднення підземних вод із достатньою точністю описується рівняннями руху та збереження маси речовини, якщо коефіцієнт гідродисперсії обчислюється iз розв'язання інверсних задач за даними режимних спостережень.

5. Епігнозні розрахунки та їх співставлення 3 режимними спостереженнями - надійний доказ 
адекватності створеної математичної моделі природним процесам і високої достовірності всіх видів задач, які розв’язуються на моделі.

6. Для припинення подальшого увагу проблемам їх очищення та подальшого використання.

забруднення підземних вод необхідно приділити

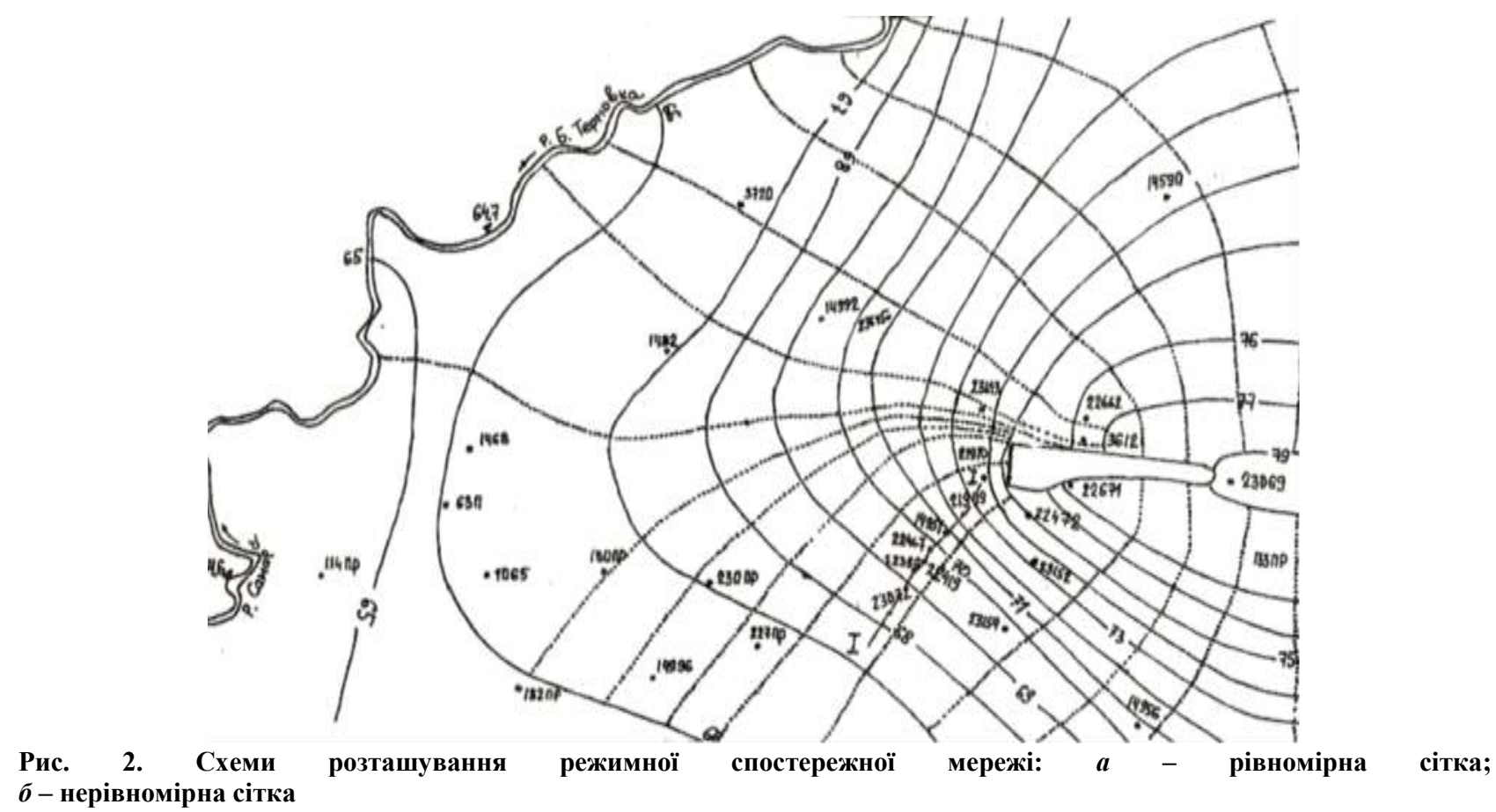

\section{Бібліографічні посилання}

Brenner, H., 1978. The diffusion model of longitudinal mixing in beds of finite length. Chem. Eng. Sci., 17(4), 229-243.

Mironenko, V.A., 1993. O koncepcii gosudarstvennogo gidrogeologicheskogo monitoring [About the state of concept hydrological monitoring]. Geoecology 1, 19-29 (in Russian).

Samarskij, A.A., 1977. Teorija rasnostnyh shem [The theory of difference schemes]. Moscow: Nauka.

Shestakov, V.M., 1979. Dinamika podzemnyh vod [The dynamics of groundwater]. Moscow: (in Russian).
Yevgrashkina, G.P., 2003. Prud-nakopitel sbrosnyh shahtnyh vod «Svidovok» v Zapadnom Donbasse i ego jekologicheskie problem [The storage pond waste mine waters "Svidovok" in the Western Donbass and its environmental problems]. Ekologia dovkilla ta bezpeka zhyttjedijal'nosti. 5, 48-53 (in Ukrainian).

Yevgrashkina, G.P., 2003. Vlijanie gornodobyvajushei promyshlennosti na gidrologicheskie pochvenno-meliorativnye uslovia territorij [The impact of mining industry on hydrological and soil-reclamation condinions and territories]. Dnepropetrovsk: Monolit (in Russian). 